\title{
Urolithiasis and Its Herbal Remedies
}

\section{A. R. Dhole ${ }^{1}$, V. C. Yeligar ${ }^{2}$}

${ }^{1}$ Assistant Professor Rajarambapu College of Pharmacy, Kasegaon, Taluka - Walwa, Sangli, Maharashtra, India

${ }^{2}$ Associate Professor, Ashokrao Mane College of Pharmacy, Pethvadgaon, Peth-Vadgaon, Tal- Hatkanangle, Dist- Kolhapur, Kolhapur, Maharashtra, India

\begin{abstract}
Urolithiasis (UL) is one of the most common diseases, with worldwide increasing incidence and prevalence. In India, in the Ayurvedic system of medicine, 'Pashanabheda' group plants, claimed to be useful in the treatment of urinary stones. 'Pashanabheda' is the Sanskrit term used for a group of plants with diuretic and antiurolithiatic activities (Pashana = stone; Bheda = break). Hence, in the present review an attempt has been made to enumerate the studies of plants Cessampelous pareira linn, B. Sensitivum linn, Fragaria vesca linn used for antiurolithiasis. This could serve as a source of information on the present trends in research on plants accredited with antiurolithiatic activity.
\end{abstract}

Keywords : Urolithiasis, Cessampelous pareira, B. Sensitivum, Fragaria vesca

\section{INTRODUCTION}

The formation of stone in the urinary system, i.e. in the kidney, ureter, and urinary bladder or in the urethra is called urolithiasis. 'Urolithiasis' = ouron (urine) and lithos (stone). Urolithiasis is one of the major diseases of the urinary tract and is a major source of morbidity.[1] Although most patients have only one stone episode, $25 \%$ of patients experience recurrent stone formation[2]. Urinary stone disease remains rare in children with a stable overall incidence in most series. As in adults, factors implicated in the metabolic syndrome complex such as obesity pose risks for urinary stone formation in children. [3] Urolithiasis remains a disease with a clear predominance in males for all stone compositions.

\subsection{Types of Urolithiasis}

The stone type is named after its mineral composition. The most common stones are are struvite (magnesium ammonium phosphate), calcium oxalate, urate, cystine and silica. [4]

Table 1. Types of stone commonly found in urolithiasis

\begin{tabular}{|c|c|}
\hline Name of stone & Approximate incidence \\
\hline Calcium oxalate & $70 \%$ of all stones \\
\hline Calcium phosphate & $10 \%$ of all stones \\
\hline Uric acid & $5-10 \%$ \\
\hline Struvite & $10 \%$ \\
\hline Cystine & Less than $1 \%$ \\
\hline
\end{tabular}

\subsection{Pathogenesis and pathophysiology}

Urinary stone formation is a result of different mechanisms. Whereas exceeding supersaturation (ie, free stone formation) is the cause of uric acid or cystine calculi, infection stones result from bacterial metabolism[5]. The formation of the most common fraction, the calcium-containing calculi, is more 
complex and, surprisingly, is not yet completely understood.

In India, in the Ayurvedic system of medicine, 'Pashanabheda' group plants, claimed to be useful in the treatment of urinary stones. 'Pashanabheda' is the Sanskrit term used for a group of plants with diuretic and antiurolithiatic activities (Pashana = stone; Bheda = break). Hence, in the present review an attempt has been made to enumerate the studies carried out on these plants[6]

\section{Mechanism of action of Phytotherapeutic Agents :}

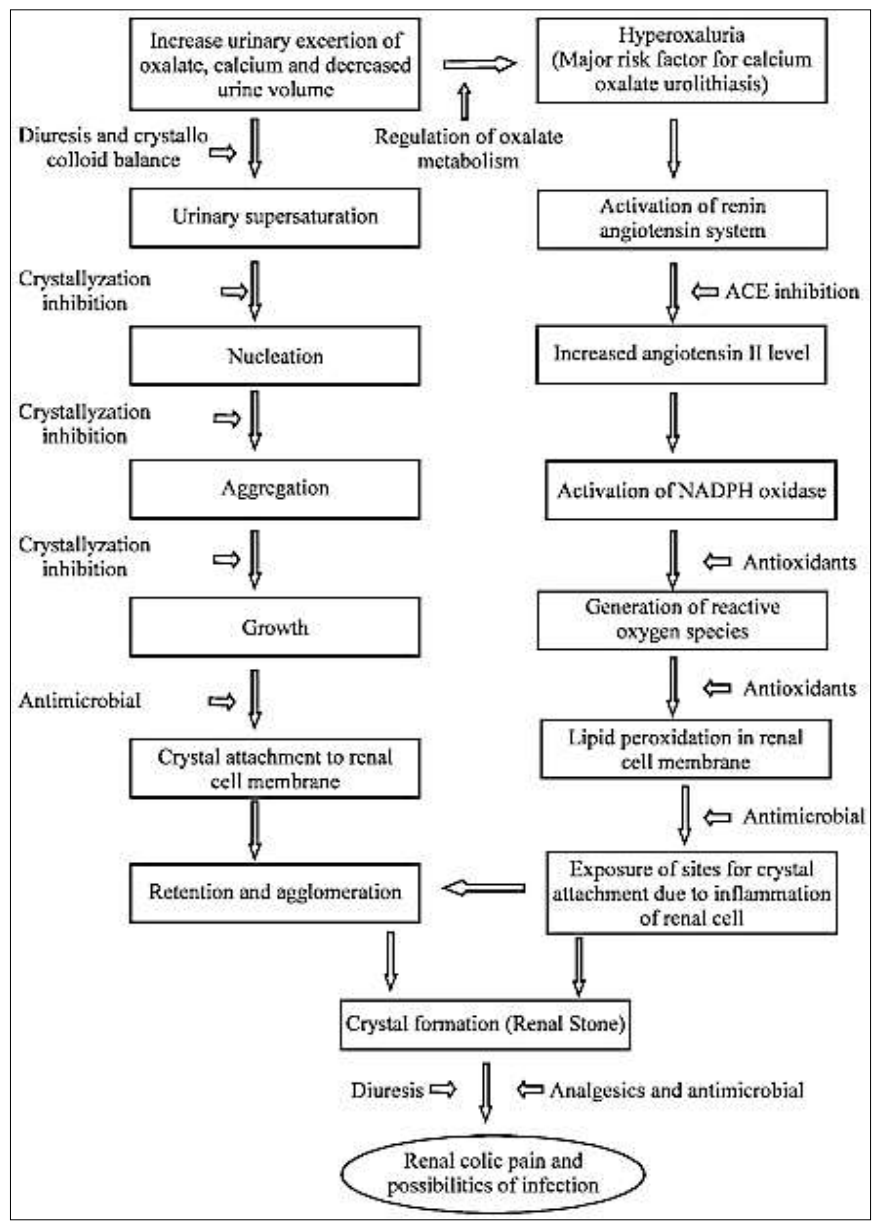

Fig 1. Mechanism of action of Phytotherapeutic Agents

Herbal medicines have several phytoconstituent and exert their beneficial effects urolithiasis by multiple mechanisms like:
- Helps in spontaneous passage of calculi by increasing urine volume, $\mathrm{pH}$ and anti-calcifying activity (Diuretic activity)

- Balance the Inhibitor and promoter of the crystallization in urine and affects the crystal nucleation, aggregation and growth (Crystallization inhibition activity)

- Relieves the binding mucin of calculi (lithotriptic activity)

- Improved renal function

- Regulation of oxalate metabolism

- Regulates the crystalloid colloid imbalance and improve renal function, thus prevents recurrence of urinary calculi

- Improve renal tissue antioxidant status and cell membrane integrity and prevent reoccurrence (Antioxidant activity)

- ACE and Phospholipase A2 Inhibition

- Exerts significant anti-infective action in against the major causative organisms (Antimicrobial activity)

- Reveals marked improvement in symptoms of urinary calculi like pain, burning micturition and haematuria (Analgesic and anti-inflammatory activity)[7]

Following are the plants which are used in ancient Ayurveda for treating urolithiasis.

\section{CESSAMPELOUS PAREIRA}

Cissampelos pareira Linn.Belongs to the family Menispermaceae is a sub-erect or climbing herb, known as ambastha or laghupatha in Indian traditional medicine.[8]It has botanical name as Cissampelos pareiraL. var. hirsuta (DC.) 


\subsection{Synonyms / Common Names / Related Terms}

Hirsute Buch. Ham ex DC; C pareira (pro parte), Abuta fluminum, Abuta grandifolia, Abuta grisebachii, Abuta panurensis, ice vine, Menispermaceae, pareira, pareira brava, velvet leaf

\subsection{Taxonomic Position [9]}

Kingdom : Plantae

Subkingdom : Tracheobionta

Super division : Spermatophyta

Division : Magnoliophyta

Class : Magnoliopsida

Order : Solanales

Family : Convolvulaceae

Genus : Convolvulus

Species : arvensis

\subsection{Pharmacognosy}

Roots are cylindrical, often tortuous. $1-1.5 \mathrm{~cm}$ in diameter, light brown to yellowish in colour, surface rough and at places rugged due to transverse wrinkles cracks and fissures. Fracture is short and splintery, odour faint aromatic, taste biter. T.S. of root shows 610 layered tangentially enlogated cells. Xylem consists of vessels, tracheids, fibers and xylem parenchyma. Vessels of tracheids show simple pits on the walls. Xylem parenchyma. Vessels of tracheids show simple and lignified but due to delignification. Medullary rays are 1-3 seriate.[10]

\subsection{Phyto-constituents[11]}

Alkaloids, viz. hayatine ( \pm curine), hayatinine, hayatidine and other bisbenzylisoquinoline alkaloids, some non nitrogenous components, e.g., quercitol and sterol (root); cyclanoline chlorides, a non phenolic tertiary alkaloid (tetra hydroisoquinoline chromophone), alkaloids viz., seepeerine, berberine, cissampeline, pelosine (or berberine), hayatin, hayatinin, l-curine and d-isochondrodendrine along witha saponin, quaternary ammonium bases, $d-$ quercetol and sterol.

\subsection{Biological Review}

Although this plant has been widely used in various symptoms and diseases, however few pharmacological studies have been reported.

\subsubsection{Antinociceptive and anti-arthritic activity}

$50 \%$ aqueous ethanolic extract of roots of $\mathrm{C}$. pareiraat the dose levels of $100-400 \mathrm{mg} / \mathrm{kg}$ exhibited significant resistance against mechanical pain in analgesymeter induced pain in mice. Study also suggested that dose dependent significant protective effect of plant against complete Freund's adjuvant induced arthritis [12]

\subsubsection{Anti-inflammatory activity}

Ethanolic extract of C. pareira aerial partsexhibited significant and dose dependent anti-inflammatory activity in he carrageenan test, which has been confirmed by the arachidonic acid test (Amresh et al., 2007).Ethanolic extract (50\%) of Cissampelos pareira roots in acute, subacute and chronic models of inflammation exhibited significant anti-inflammatory activity(13).The methanolic extract showed significant anti-inflammatory activity similar to ibuprofen and indomethacin.

\subsubsection{Anti-Lithiasis effects}

The root extract reduced the lithiasis confirmed by the reduced level of urinary oxalate and calcium in ethylene glycol induced lithiasis in rats. [14] 
Table 2 : Research studies carried out on C.pareira can be summarized as given under [15]

\begin{tabular}{|c|c|c|c|}
\hline $\begin{array}{l}\text { Name of the } \\
\text { plant }\end{array}$ & Activities & Extract & Part used \\
\hline C .pareira & $\begin{array}{l}\text { a. Antioxidant } \\
\text { b. Antifertility } \\
\text { c. Chemopreventive } \\
\text { d. Anti-haemorrhagic } \\
\text { e.Antinociceptive \& } \\
\text { Antiarthritic } \\
\text { f. Anti-inflammatory } \\
\text { g. Gastroprotective } \\
\text { h. Cardioprotective } \\
\text { i. Anti-diarrhoeal } \\
\text { j. Hepatoprotective } \\
\text { k. Memory enhancing } \\
\text { l. Anti-hyperglycemic }\end{array}$ & $\begin{array}{l}\text { Ethanolic } \\
\text { Hydro- } \\
\text { alcoholic } \\
\text { Hydro- } \\
\text { alcoholic } \\
\text { Aqueous } \\
\text { Ethanolic } \\
\text { Ethanolic } \\
\text { Ethanolic } \\
\text { Ethanolic } \\
\text { Ethanolic } \\
\text { Hydro- } \\
\text { alcoholic } \\
\text { Hydro- } \\
\text { alcoholic } \\
\text { Methanolic }\end{array}$ & $\begin{array}{l}\text { Root } \\
\text { Leaves } \\
\text { Root } \\
\text { Leaves } \\
\text { Root } \\
\text { Aerial part } \\
\text { Root } \\
\text { Root } \\
\text { Root } \\
\text { Root } \\
\text { Root } \\
\text { Root }\end{array}$ \\
\hline
\end{tabular}

\section{BIOPHYTUM SENSITIVUM}

\subsection{Occurrence and Botanical Description}

Biophytum sensitivum (L: Linnaeus) DC belongs to

Division: Magnoliophyta,

Class: Magnoliopsida,

Order: Oxalidales,

Family: Oxalidaceae

These are found in wet lands of tropical India, South Asia and Africa. Normally, it is present in the shades of trees and shrubs, in grass lands at low and medium altitudes. It is commonly known as Life plant (English).

3.2 Vernacular names : Jhalai (Bengali), Laajjaalu, Lakshmana (Hindi), Har muni, Jalapushpa (Kannada), Mukkutti (Malayalam), Lajwanti (Marathi), Vipareetalajjaalu, Jhulapushpa (Sanskrit), Nilaccurunki, Tintaanaalee (Tamil), Attapatti, chumi, Jalapuspa, (Telugu).[16]

\subsection{Plant morphology}

The little plant grows up to maximum of $20 \mathrm{~cm}$ and possess unbranched woody erect stem. Leaves: Leaves abruptly pinnate, leaflets opposite, 6 to 12 pairs, and each leaflet is up to $1.5 \mathrm{~cm}$ long, the terminal pair is the largest. The flowers are many and crowded at the apices of the numerous peduncles, normally yellow, white, or orange with red streak in the center of each of the five petals. The sepals are subulate-lanceolate, striate, and about $7 \mathrm{~mm}$ long. Fruits are ellipsoid capsules which are shorter than the persistent calyx [17]

\subsection{Phytochemistry}

The phytochemistry of $B$. sensitivum showed a wide range of chemical compounds including two biflavones: cupressu flavone and amentoflavone; three flavonoids : luteolin 7- methyl ether, isoorientin and 3'-methoxyluteolin 7-O-glucoside; two acids: 4-Caffeoylquinic acid and 5-Caffeoylquinic acid which were isolated from the aerial parts of $B$. sensitivum. [18] It also contains 3', 8"-biapigenin, [19] proanthocyanidins (also known as condensed form of tannins), [20] and some phenolic compounds. These compounds were isolated from the aerial part of this plant.

\subsection{Pharmacological potential of B. Sensitivum Linn}

Biophytum sensitivum can be used for radio protection, immune modulation, antitumor, antioxidant, antibacterial, hypoglycemic, antimetastatic, anti-angiogenesis, chemoprevention, antidiabetic, anti-inflammatory. The widest spectra of pharmacological activities exhibited by $B$. sensitivum are represented in the Figure 2. 


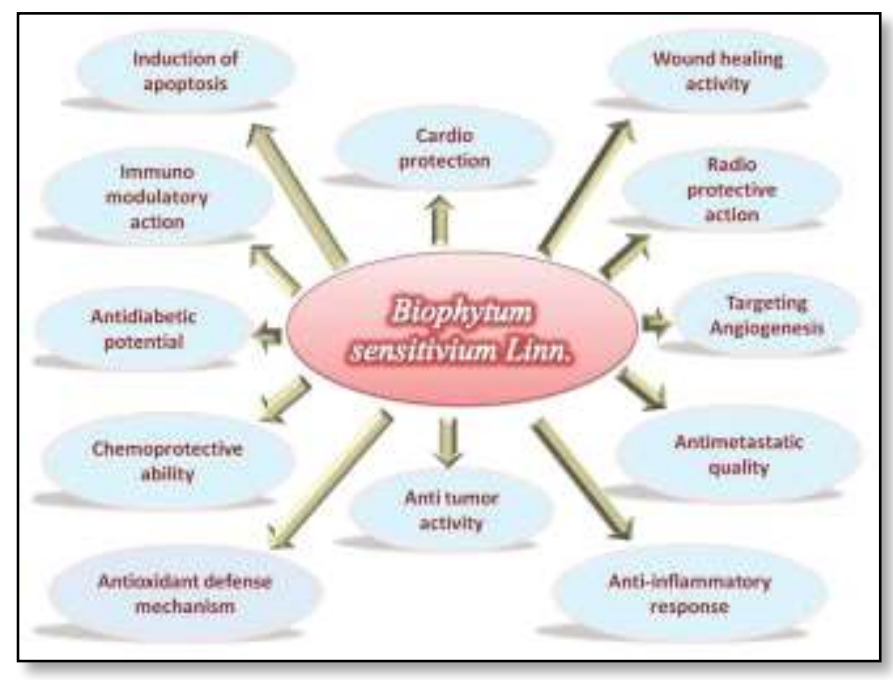

Fig 2. pharmacological activities of $B$. sensitivum

\subsubsection{Urolithiatic effect [21]}

There is the use of $B$. sensitivum in folk medicine against urolithiasis. Administration of whole plant extract of $B$. sensitivum reduces and prevents the growth of urinary stones. Preventive effect of plant is more effective than its curative treatment. Therefore, the whole plant extract of $B$. sensitivum is helpful to prevent the recurrence of the disease. The mechanism underlying this effect is mediated collectively through diuretic, antioxidant, and nephroprotective properties and lowering the concentration of urinary stone-forming constituents.

\subsubsection{Anti-inflammatory activity}

Amentoflavone (I3', II8-biapigenin) was isolated from the roots of B. sensitivum DC (Oxalidaceae) and proved to be a selective inhibitor of cycloxygenase (COX)-1 catalyzed prostaglandin biosynthesis when tested in vitro, with an IC50 value of $12.4 \mathrm{mM}$ (standard: indomethacin, IC50 $=1.1 \mathrm{mM}$ ). [22] The dose-dependent study indicated that prostaglandin E2 (PGE2) production was inhibited both at 10 and 50 $\mathrm{mM}$ concentrations of amentoflavone by 52 and $55.5 \%$, respectively. Inhibitory effects of amentoflavone on PGE2 biosynthesis and on NO production were associated with COX-2 and iNOS
mRNA expression, by a rise in NO and corresponding enzyme. [23] A comparative study was done in the carrageenan-induced rat paw edema model. It was found that the aqueous extract had maximum edema inhibition in comparison to the methanolic extract of root and aerial part .

\section{FRAGARIA VESCA}

Fragaria vesca, commonly called wild strawberry, woodland strawberry, Alpine strawberry, European strawberry, or fraise des bois, is a perennial herbaceous plant in the rose family that grows naturally throughout much of the Northern Hemisphere, and that produces edible fruit.[24][25]

\subsection{Description}

$\checkmark$ Synonym: Woodland Strawberry

$\checkmark$ Family: Rose Family - Rosaceae

$\checkmark$ Growing form: Perennial herb. With runners.

$\checkmark$ Height: 5-20 cm (2-8 in.), runners up to $2 \mathrm{~m}$ (80

in.) long. Stem hairs ascending obliquespreading.

Five to eleven soft, hairy white flowers are borne on a green, soft-hairy 3-15 centimetres (1.2-5.9 in) stalk that usually lifts them above the leaves. The lightgreen leaves are trifoliate (in threes) with toothed margins. The plant spreads by means of runners.

\subsection{Chemical Constituents}

Cissotanic, malic, and citric acids, sugar, mucilage and a peculiar volatile aromatic body uninvestigated. Bacon found in the odour of the dying leaves 'a most excellent cordial smell, ' next in sweetness to the muskrose and violet .

\subsection{Pharmacological uses}

The root is astringent and used in diarrhea. The leaves have the same property, and a tea made from 
them checks dysentery. The Strawberry is a useful dentifrice and cosmetic. In the traditional system of medicine, the plant is said to be possess diuretic and liver tonic property. It is also used as nephroprotective drug. By acting as diuretic drug Fragaria vesca, exhibits its urolithiatic action.

\section{CONCLUSION}

In Ayurveda, many plants having the property of disintegrating and dissolving the stone are referred to as "Pashanbheda" .Herbal medicines have many phytoconstituents which may exert their beneficial effect in kidney stone treatment. Plant extracts contain phytochemicals that inhibit stone formation by inhibiting synthesis and agglomeration of crystals. Herbal extracts may prevent stone formation because of many reasons like they may have diuretic activity, crystallization inhibiting activity, lithotriptic activity, analgesic and anti-inflammatory activity and finally regulate oxalate metabolism which help in reducing the reoccurrence of renal calculi. Herbal remedies are reported to be effective with no side effects. The combination of traditional and modern knowledge can produce better antiulcer drugs with fewer side effects. Herbs are widely available in India and other countries. The wide spectrum makes them attractive candidates for further research.

\section{REFERENCES}

[1]. Soundararajan $\mathrm{P}$, Mahesh $\mathrm{R}$, Ramesh $\mathrm{T}$, Hazeena Begum V. Effect of Aerva Lanata on calcium oxalate urolithiasis in rats. Indian journal oexperimental biology, 44, 2006, 981986. 2.

[2]. Hesse A, Brandle E, Wilbert D, Kohrmann K-U, Alken P. Study on the prevalence and incidence of urolithiasis in Germany comparing the years 1979 vs. 2000. Eur Urol 2003;44:70913
[3]. Sarica K, Eryildirim B, Yencilek F, Kuyumcuoglu U. Role of over- weight status on stone-forming risk factors in children: a prospec-tive study. Urology 2009;73:1003-7

[4]. C.Turk (chairman),T.K.c.(2011).guidelines on urolithiasis.update march 2011,1-103

[5]. Moe OW. Kidney stones: pathophysiology and medical manage-ment. Lancet 2006;367:33344.

[6]. Bahl and Seshadri Advances in research in "Indian Medicine", "Pashanbedi" drugs for urinary calculus, Udupa, K.N. (Eds),: 1970 : 7798.

[7]. Surendra K. Pareta, Kartik C. Patra, Papiya M. Mazumder and Dinakar Sasmal, 2011. Establishing the Principle of Herbal Therapy for Antiurolithiatic Activity: A Review. Journal of Pharmacology and Toxicology, 6: 321-332

[8]. Vaidya GB,Adarsa N. 2nded., Vol. 1. Chaukhambha Bharti Academy Publications; 1998

[9]. Coombs EM Biological Control of Invasive Plants in the United States. Corvallis: Oregon State University Press 2004.

[10]. S.K. Jain, Swadesh kumar Ahirwar .Review of Cissampelos pareira Linn. International Journal of Applied Research 2015; 1(6): 08-09

[11]. Anonymous, Database on Medicinal Plants used in Ayurveda, vol 2, New Delhi, CCRAS, Dept of HFW, Reprint 2005: 438

[12]. G Amresh, PN Singh, CV Rao, Antinociceptive and antiarthritic activity of Cissampelos pareira roots-Journal of ethnopharmacology, 2007, 111: 531-536

[13]. G. Amresh,G.D. Reddy, Ch.V. Rao,P.N. Singh,Evaluation of anti-inflammatory activity of Cissampelos pareira root in rats, J Ethnopharmacol.2007 Apr 4;110(3):526-31

[14]. Christina AJM, Packialakshmi M.Nagarajan M, Kurian S., Modulatory effect of Cyclea peltata Lam on stone formation induced by Ethylene 
Glycol Treatment in rats., Methods Find Exp Clin Pharmacol. 2002; 24:77-79

[15]. Suman Singh, Nishteswar K Review on Cissampelos Pareira \& CycleaPeltata (Patha Dwaya) Phyto-Pharmacological Perspectives International Journal of Ayurvedic Medicine, 2013, 4(4), 282-289

[16]. Varghese KJ, Anila J, Nagalekshmi R, Resiya S, Dasapushpam JS. The traditional uses and the therapeutic potential of ten sacred plants of Kerala state in India. International journal of pharmaceutical sciences and research 2010; : 50-59.

[17]. Kirtikar KR, Basu BD. Indian medicinal plants. Dehradun, India: International book distributors; 2005. p. 3.

[18]. Lin YL, Wang WY. Chemical constituents of Biophytum sensitivum.Chin Pharm Jr 2003;55:71-5.

[19]. Jachak SM, Bucar F, Kartnig TH, ShubertZsilavecz M.C-Glycosylflavones from B. sensitivum leaves. Prague, Czech Republic: 44th Annual Congress of the society for Medicinal Plant Research; 1996: p.188.

[20]. Bucar FS, Jachak M, Kartnig TH, Noreen Y, Bohlin L, Schubert- Zsilavecz M. Phenolic compounds of Biophytum sensitivum and their activities on COX catalyzed prostaglandin biosynthesis,International Symposium of Bioassay methods in Natural Product Research and Drug Development, Uppsala University, Uppsala, Sweden: Swedish Academy of Pharmaceutical Sciences; 1997: p.49.

[21]. Anil T. Pawara Protective effect of standardized extract of Biophytum sensitivum against calcium oxalate urolithiasis in rats Bulletin of Faculty of Pharmacy, Cairo University 53 (2) 2015, 161-172

[22]. Jachak SM, Bucar F, Kartnig TH, ShubertZsilavecz M.C-Glycosylflavones from B. sensitivum leaves. Prague, Czech Republic: 44th Annual Congress of the society for Medicinal Plant Research; 1996: p.188.

[23]. Gomes A, Das R, Sarkhel S, Mishra R, Mukherjee S, Bhattacharya S,et al. Herbs and Herbal constituents active against Snake bite. Indian J Ex boil 2010;48:865-78.

[24]. Sullivan, Steven. K. (2015). "Fragaria vesca". Wildflower Search. Retrieved 2015-06-16.

[25]. "Fragaria vesca". PLANTS Database. United States Department of Agriculture; Natural Resources Conservation Service. 2015. Retrieved 2015-06-16 